\title{
Rapid detection of Akabane virus by a novel reverse transcription loop-mediated isothermal amplification assay (RT-LAMP)
}

\author{
Jun Qiao ${ }^{1}$, Junwei Wang ${ }^{1}$, Qingling Meng ${ }^{1,2^{*}}$, Guochao Wang ${ }^{1}$, Yucheng Liu' ${ }^{1}$ Z Zhihao He ${ }^{1}$, Haibo Yang ${ }^{1}$, \\ Zaichao Zhang ${ }^{1}$, Xuepeng $\mathrm{Cai}^{2}$ and Chuangfu Chen ${ }^{1}$
}

\begin{abstract}
Background: Akabane disease, caused by Akabane virus, is an insect-transmitted disease of ruminants that is primarily characterized by fetal damage.

Methods and results: In this study, a novel reverse transcription loop-mediated isothermal amplification (RT-LAMP) assay for rapid detection of Akabane virus was successfully developed. The primers were designed to target the highly conserved fragment of nucleoprotein from the Akabane virus. The results indicate that the assay is highly specific and sensitive with a detection limit of $5.0 \mathrm{TCID}_{50} / \mathrm{mL}$ within a 60 -min incubation time. A total of 126 abortive samples collected from Xinjiang province were detected by the established RT-LAMP. The results of RT-LAMP assay showed $96.8 \%$ agreement with the semi-nested RT-PCR.
\end{abstract}

Conclusion: This study is to first to develop a rapid, sensitive, and accurate method for the detection of Akabane virus, which may be used to screen clinical samples in developing countries or regions.

Keywords: Rapid detection, Akabane virus, Reverse transcription loop-mediated isothermal amplification assay

\section{Background}

Akabane virus, the causative agent of enzootic bovine arthrogryposis and hydranencephaly, is an arbovirus in the genus Orthobunyavirus and the Simbu sero-group of the family Bunyaviridae. This particular virus is transmitted among animals by hematophagous arthropod vectors such as mosquitoes and culicoides biting midges [1]. The infection of Akabane virus in pregnant cows can lead to a series of endemic and abnormal deliveries such as abortion, premature birth, stillbirth, and birth of abnormal calves [1-5]. Between 1972 to 1975, more than 40,000 cattle were infected in Japan [6], which resulted in a huge economic loss to the cattle industry. To date, Akabane disease is widely prevalent in Japan, Korea, Israel, Central Africa, and Australia [1,4,5,7,8].

\footnotetext{
* Correspondence: xjmqlqj@163.com

${ }^{1}$ College of Animal Science and Technology, Shihezi University, Shihezi, Xinjiang 832003, People's Republic of China

${ }^{2}$ State Key Lab of Veterinary Etiological Biology, Lanzhou Veterinary Research Institute, Chinese Academy of Agricultural Sciences, Lanzhou, Gansu 730046, People's Republic of China
}

Although laboratory diagnostic techniques for Akabane disease such as viral neutralization test (VNT), enzymelinked immunosorbent assays (ELISAs) [9-12], immunoperoxidase staining $[13,14]$, dot immunobinding assay [15], nested reverse transcription polymerase chain reaction (RT-PCR) [16], multiplex RT-PCR [17] and real-time RT-PCR [18] have been established, most of the current serological tests have cross-reactions with other related viruses, particularly those in the simbu serogroup $[9,15,19]$. PCR-based molecular techniques need specialized equipment and may not be readily available in diagnostic laboratories of underdeveloped and developed countries [16]. Viral isolation from aborted fetus is rarely successful because of an elicited immune response that inhibits virus replication. Therefore, it is necessary to develop new assays for the detection of Akabane virus in the clinic.

In this study, we demonstrated that loop-mediated isothermal amplification (LAMP) provides a new method for molecular diagnosis [20]. LAMP has been widely used to detect different pathogens because of its rapid detection $[21,22]$. The aim of this study is to develop a

\section{Biomed Central}

(C) 2013 Qiao et al.; licensee BioMed Central Ltd. This is an Open Access article distributed under the terms of the Creative Commons Attribution License (http://creativecommons.org/licenses/by/2.0), which permits unrestricted use, distribution, and reproduction in any medium, provided the original work is properly cited. 
rapid and accurate molecular tool for detecting Akabane virus in clinical specimens.

\section{Results and discussion}

The results demonstrated that only Akabane virus was detectable by RT-LAMP assay (Figure 1). In contrast, this assay did not detect the other tested viral strains. Following AccIII digestion, the amplification products appeared as 2 fragments with sizes of 33 and $180 \mathrm{bp}$ (Figure 2). The results also showed that the RT-LAMP assay is highly sensitive as it can detect a template at $10^{-5}$ dilution with a detection limit of $5.0 \mathrm{TCID}_{50} / \mathrm{mL}$ (Figure 3). RT-LAMP exhibited high concordance with the semi-nested RT-PCR for Akabane virus detection in clinical samples (Table 1). Fifty-one out of 126 samples were positive for the Akabane virus using both RTLAMP and semi-nested RT-PCR assays. One negative sample from semi-nested RT-PCR was positive by RTLAMP assay, and 3 negative samples from RT-LAMP assay were positive by semi-nested RT-PCR. An additional seventy-one samples also were negative from both assays. Accordingly, the cohen's kappa coefficient for these two assays was $96.62 \%$.

In this study, we report a novel and rapid molecular detection technique named RT-LAMP assay to detect Akabane virus from clinical samples with high specificity (Figure 2). This assay can distinguish Akabane virus from other four viruses known to cause abortion in cattle (bovine herpesvirus 1, bovine parvovirus, bluetongue virus, and bovine viral diarrhea virus). In addition, the developed RT-LAMP is simple and rapid compared to other molecular detection assays (single RT-PCR, nested RT-PCR, or real-time RT-PCR). Therefore, RT-LAMP has great potential for use as a field test to detect Akabane viral infection.

A critical factor when performing the RT-LAMP assay is to select a conserved nucleic acid fragment for the design of specific primers. In the present study, 25 sequences of the nucleoprotein gene of Akabane virus reported in GenBank were analyzed, and a highly conserved fragment was chosen as the target region (Figure 4). Two pairs of specific primers (two inner primers and two outer primers) were designed using the Primer Explorer Version 4 software. On these bases, these primers were further analyzed by Blast $\mathrm{N}$ software. The rigorous selection and analysis of high conservation fragment are conducive to the specificity of established RT-LAMP.

The detection of positive amplification of RT-LAMP can be accomplished by agarose gel electrophoresis and real-time monitoring using a turbidimeter. In addition, amplification of the target gene can also be visualized by a fluorescent intercalating dye. In this study, SYBR Green I was used for detection of the amplified products by observing color change. The orange color of the dye will fluoresce green under natural light with positive amplification. For the cases with no amplification, the orange color of the dye is retained.

We show that the RT-LAMP assay using 126 clinical samples demonstrated that the RT-LAMP assay is high sensitive and accurate, similar to the semi-nested RTPCR assay. The detection method also demonstrated that the Akabane virus infection is common in calves for various geographical areas of Xinjiang province. Thus, preventive measures are recommended for the cattle industry.

In conclusion, a novel RT-LAMP assay was successfully developed for the rapid detection of Akabane virus genomic RNA in clinical samples from abortive cases. The assay is highly sensitive and specific. This rapid, easy-to-operate, and sensitive assay can be used for the diagnosis and epidemiological surveillance of Akabane virus infection in resource-limited countries or regions.

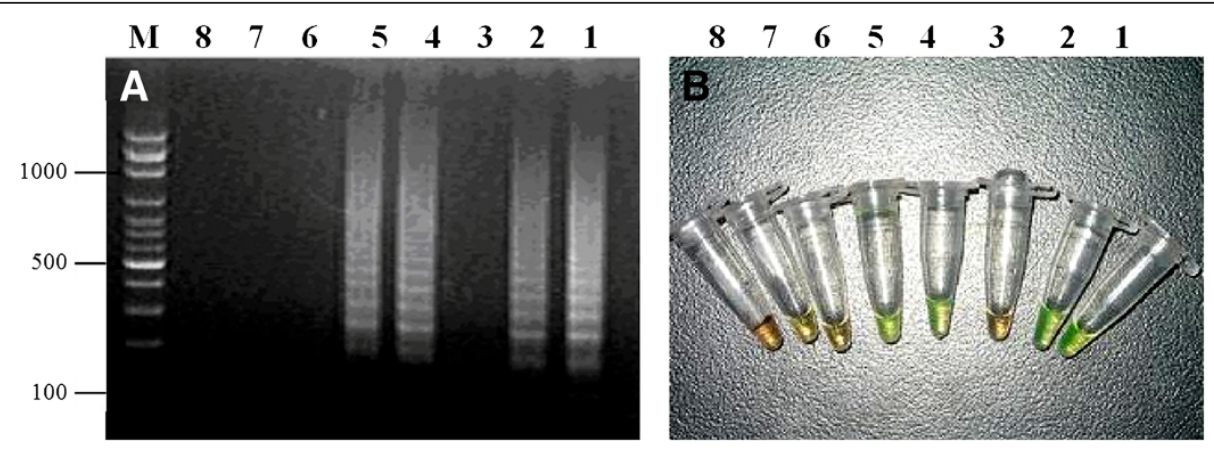

Figure 1 Specificity of RT-LAMP. A, Agarose gel electrophoresis showing the specificity of RT-LAMP on amplification of different viruses. B, Visual detection of RT-LAMP amplification products of the different viruses using SYBR Green I staining. The color change from orange in the negative to green in the positive reaction. The lane and tube numbers correspond to the following specimens: Lanes 1, 2, 4 and 5, Akabane virus strain JaGAR 39/MB19; Lane 3, Bovine herpesvirus 1 strain 758; Lane 6, Bovine parvovirus strain BF15; Lane 7, Bluetongue virus strain CSIRO 154; Lane 8, Bovine viral diarrhea virus strain NADL; Lane M, 100-bp DNA Ladder. 

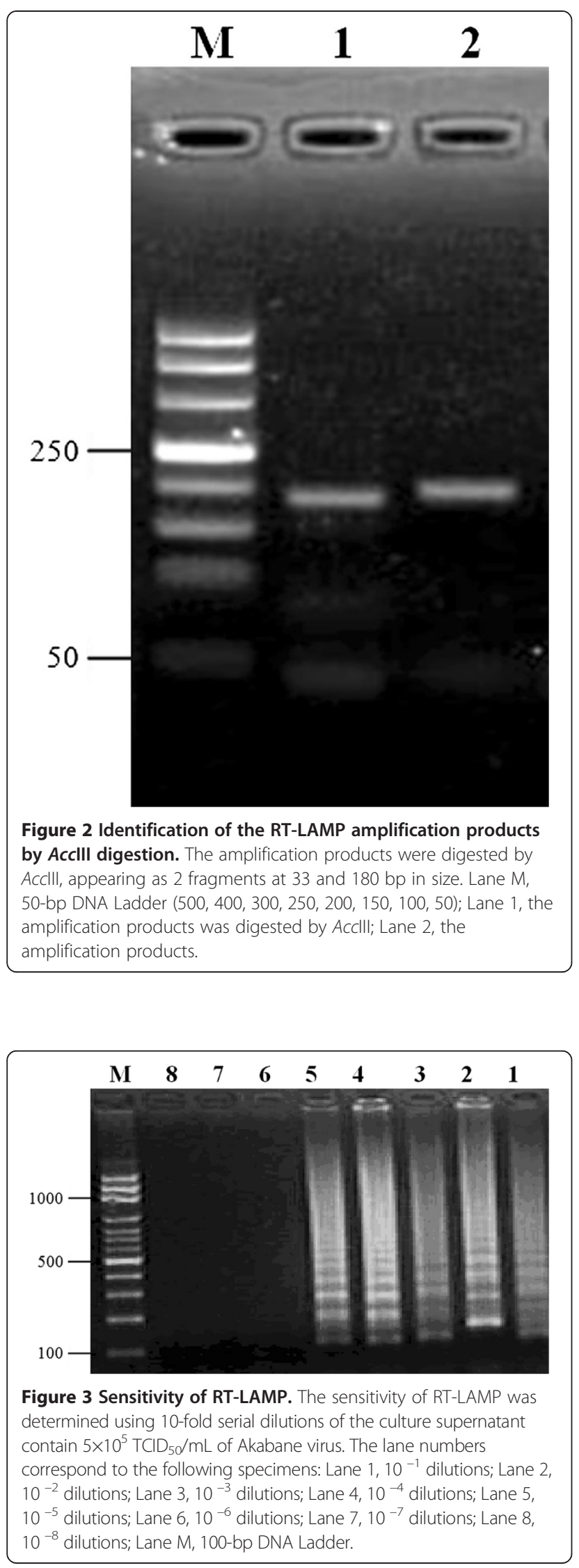

Table 1 Comparative analysis of clinical samples for Akabane virus positivity by RT-LAMP assay and semi-nested RT-PCR

\begin{tabular}{llll}
\hline RT-LAMP & \multicolumn{3}{c}{ Semi-nested RT-PCR } \\
\cline { 2 - 4 } assay & Positive & Negative & Total \\
\hline Positive & 51 & 1 & $52(41.27 \%)$ \\
Negative & 3 & 71 & $74(58.73 \%)$ \\
Total & $54(42.86 \%)$ & $72(57.14 \%)$ & 126 \\
\hline
\end{tabular}

\section{Materials and methods}

\section{Collection of clinical samples}

A total of 126 clinical samples were from aborted bovine fetuses from 8 cattle farms located in 6 geographical areas (Taichen, Kuitun, Yili, Shihezi, Manas, Shawan) of Xinjiang province, China during October 2008 through February 2011. These samples consisted of brain, muscles, spleen, kidney, heart, lung, and lymph nodes. Samples were kept cool by the staff of the Ili Kazakh Autonomous Prefecture Center of Animal Disease Control and Diagnosis and delivered on ice to key laboratory of the Preventive Veterinary Medicine, College of Animal Science, and Technology (Shihezi University) within 24-48 h.

\section{Viruses and cells}

Akabane virus strain JaGAR 39/MB19 was originally supplied by Dr Inaba of the National Institute of Animal Health, Japan. BHK-21 cells were maintained in minimum essential medium (MEM, Invitrogen, Carlsbad, CA, USA) containing 10\% fetal bovine serum (FBS, Biofluid, Richmond, VA, USA). Bovine herpesvirus 1 strain 758 , bovine parvovirus strain BF15, bluetongue virus strain CSIRO 154, and bovine viral diarrhea virus strain NADL were provided by the State Key Lab of Veterinary Etiological Biology.

\section{Design of specific RT-LAMP primers}

Nucleoprotein (N) gene sequences of 25 different strains/isolates of Akabane virus were obtained from GenBank, and the homology was analyzed using the molecular software DNAMAN. The conserved fragment with high homology was chosen to be the target region (Figure 4) which was used to design the Akabane virus RT-LAMP primers by the Primer Explorer V4 software (http://primerexplorer.jp/e/) (Table 2), as previously described by Notomi et al. [20].

\section{RNA extraction}

Total RNA was extracted from Akabane virus-infected BHK-21 cells or clinical samples with SV-total RNA Isolation System (Promega, Mannheim, Germany), according to the manufacturer's protocol. The RNA was eluted in $20 \mu \mathrm{L}$ of RNase-free water containing $0.04 \%$ 


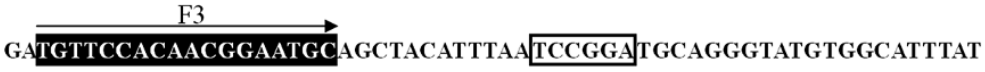

CAGTAAGTATGGGCAGCAGCTCAACTTTACTGTTGCTAGAGTCTTCTTCCTCAACCAGA

AGAAGGCCAAGATGGTCTTACATAAGACGCCACAACCAAGTGTCGATCTTACTTTTGCA

GGGGTCAAATTTACAGTGGTTAATAACCATTTTCCC

B3

Figure 4 Locations of RT-LAMP primers. Oligonucleotide primers binding sequences are indicated by arrows. The Acclll restriction site is boxed.

sodium azide and was stored at $-80^{\circ} \mathrm{C}$ until further use. The RNA concentration $(\mathrm{ng} / \mu \mathrm{L})$ was measured with a spectrophotometer.

\section{RT-LAMP}

The RT-LAMP reaction was carried out in a $25 \mu \mathrm{L}$ volume containing $12.5 \mu \mathrm{L}$ of LAMP buffer ( $20 \mathrm{mM}$ Tris$\mathrm{HCl}\left[\mathrm{pH} 8.8\right.$ ], $10 \mathrm{mM} \mathrm{KCl}, 8 \mathrm{mM} \mathrm{MgSO}{ }_{4}, 10 \mathrm{mM}\left(\mathrm{NH}_{4}\right)$ ${ }_{2} \mathrm{SO}_{4}, 0.1 \%$ Triton X-100, $0.8 \mathrm{M}$ betaine, and $1.4 \mathrm{mM}$ each of deoxynucleoside triphosphates), $2 \mu \mathrm{L}$ of primer mixture (40 pM each of FIP and BIP, and $5 \mathrm{pM}$ each of F3 and B3), $1 \mu \mathrm{L}$ of Bst DNA polymerase (8 U), $1 \mu \mathrm{L}$ of Avian myeloblastosis virus reverse transcriptase (40 U), $2 \mu \mathrm{L}$ of template RNA, and $6.5 \mu \mathrm{L}$ of distilled water. The reaction mixture was incubated at $63^{\circ} \mathrm{C}$ for $60 \mathrm{~min}$ in a heating block, followed by heating at $80^{\circ} \mathrm{C}$ for $2 \mathrm{~min}$ to terminate the reaction. After the reaction, a $10 \mu \mathrm{L}$ aliquot of the RT-LAMP product was subjected to electrophoresis in $2.0 \%$ agarose gel and visualized by staining with $0.5 \mu \mathrm{g} / \mathrm{mL}$ of ethidium bromide under ultraviolet light. For visual fluorescence detection, $1 \mu \mathrm{L}$ of a 10 -fold dilution of SYBR Green I (1000x) was added into the reaction mixture, and the positive amplification was determined according to the color change (orange and green in a negative and positive reaction, respectively).

\section{Analytical sensitivity and specificity of RT-LAMP}

To evaluate the specificity of the RT-LAMP reaction, four viruses known to cause abortion in cattle, bovine herpesvirus 1 (strain 758), bovine parvovirus (strain BF15), bluetongue virus (strain CSIRO 154) and bovine viral diarrhea virus (strain NADL) were used. To determine the sensitivity of RT-LAMP assay, the culture supernatant containing $5 \times 10^{5} \quad \mathrm{TCID}_{50} / \mathrm{mL}$ of Akabane virus was diluted 10-fold and amplified by RT-LAMP assay. For further confirmation, the amplified products were confirmed by DNA sequencing and digested with restriction enzyme AccIII (Promega) and their sizes of digested products were analyzed by electrophoresis in 3\% agarose gels. Visualization was performed by straining with ethidium bromide.

\section{Semi-nested RT-PCR}

The semi-nested RT-PCR was performed using the specific primers N1 (outer sense primer), N2 (antisense primer) and N3 (inner antisense primer) (Table 2). The N1 and N2 primers were used for the first amplification after reverse transcription reaction, while N1 and N3 were used for the second round of amplification (seminested). Briefly, RT reactions were carried out with the SuperScript III Reverse Transcriptase kit (Invitrogen) following the manufacturers protocol. Two $\mu \mathrm{L}$ of template RNA was used to synthesize the first strand cDNA at $50^{\circ} \mathrm{C}$ for $30 \mathrm{~min}$, followed by incubation at $94^{\circ} \mathrm{C}$ for $5 \mathrm{~min}$. The reaction mixture for the first PCR step consisted of $2 \mu \mathrm{L}$ of cDNA template, $250 \mathrm{nmol} / \mathrm{L}$ of each primer ( $\mathrm{N} 1$ and $\mathrm{N} 2$ ), $4 \mathrm{mmol} / \mathrm{L} \mathrm{MgCl}_{2}$, PCR buffer, $200 \mu \mathrm{mol} / \mathrm{L}$ of each deoxynucleoside triphosphate, 1.25 units of Taq DNA polymerase (TaKaRa Bio. Co., Ltd., Japan), and water to a final volume of $50 \mu \mathrm{L}$. The PCR was then carried out for 30 cycles at $94^{\circ} \mathrm{C}$ for $4 \mathrm{~min}$; 30 cycles at $94^{\circ} \mathrm{C}$ for $30 \mathrm{~s}$, annealing at $55^{\circ} \mathrm{C}$ for $30 \mathrm{~s}$, extension at $72^{\circ} \mathrm{C}$ for $1 \mathrm{~min}$; and final extension at $72^{\circ} \mathrm{C}$ for

Table 2 Oligonucleotide primers used for RT-LAMP assay and semi-nested RT-PCR against Akabane virus

\begin{tabular}{llll}
\hline Primers & Sequence (5'-3') & Nucleotide positions* & Length (bp) \\
\hline F3 & TGTTCCACAACGGAATGC & $27-44$ & 18 \\
B3 & TGTAAATTGACCCCTGCA & $198-216$ & 19 \\
FIP & GAGCTGCTGCCCATACTTACT-AGCTACATTTAATCCGGATGC & & 42 \\
BIP & TACTGTTGCTAGAGTCTTCTTCCTC-AGTAAGATCGACACTTGGTT & & 45 \\
N1 & ATGTTCCACAACGGAATGCAGC & $25-46$ & 22 \\
N2 & AGCCAGGAAAGCTCTAGCTGCAG & $680-658$ & 23 \\
N3 & GGAAAATGGTATTAACCACT & $215-235$ & 21 \\
\hline
\end{tabular}

*Nucleotide sequence position according to nucleoprotein (N) gene of Akabane virus strain 93FMX (GenBank accession number FJ498797). 
10 min. $2 \mu \mathrm{L}$ of the first amplification product was used as DNA template for each of the $25 \mu \mathrm{L}$ secondary amplifications. The conditions and concentrations of the secondary amplification were identical to those of the primary, except for the primers (N1 and N3) and extension at $72^{\circ} \mathrm{C}$ for $30 \mathrm{~s}$. The PCR products of the secondary amplification round were analyzed by $3 \%$ gel electrophoresis and stained with ethidium bromide, and confirmed by DNA sequencing.

\section{Evaluation of the RT-LAMP Using Clinical Samples}

The clinical samples were subjected to total RNA extraction as described above. The RT-LAMP assay was used to detect the presence of Akabane virus. In addition, semi-nested RT-PCR was employed to examine the presence of Akabane virus and for testing the consistency between the two assays (RT-LAMP and semi-nested RTPCR). The Cohen's kappa coefficient between RT-LAMP and semi-nested RT-PCR was calculated according to the following formula.

\section{Ethical approval}

The experiments were carried out in accordance with the guidelines issued by the Ethical Committee of Shihezi University.

\section{Abbreviations}

RT-LAMP: Reverse transcription loop-mediated isothermal amplification; RT-PCR: Reverse transcription polymerase chain reaction; N: Nucleocapsid; $\mathrm{TCID}_{50}$ : Median tissue culture infective dose; VNT: Virus neutralization test.

\section{Competing interests}

The authors declare that they have no competing interests.

\section{Authors' contributions}

$J \mathrm{Q}$ and QLM conceived of the study, analyzed the results and drafted the manuscript; JWW supervised the research, analyzed the results and helped draft the manuscript; GCW, YCL, ZHH, HBY and ZCZ performed the experiments; XPC and CFC supervised the research and helped draft the manuscript. All authors contributed to write and revise the article critically for important intellectual content and have approved the final version of the manuscript to be published.

\section{Acknowledgments}

This work was supported in parts by grant from the State Basic Research Development Program of China (973 Program) (No.2010CB530204) and the National Natural Science Foundation of China (No. 30960274).

Received: 24 January 2013 Accepted: 22 July 2013

Published: 14 September 2013

\section{References}

1. Taylor WP, Mellor PS: The distribution of Akabane virus in the Middle East. Epidemiol Infect 1994, 113:175-185.

2. Coverdale OR, Cybinski DH, St George TD: Congenital abnormalities in calves associated with Akabane virus and Aino virus. Aust Vet J 1978, 54:151-152

3. Uchida K, Murakami T, Sueyoshi M, Tsuda T, Inai K, Acorda JA, Yamaguchi R, Tateyama S: Detection of Akabane viral antigens in spontaneous lymphohistiocytic encephalomyelitis in cattle. J Vet Diagn Invest 2000, 12:518-524.
4. Kamata H, Inai K, Maeda K, Nishimura T, Arita S, Tsuda T, Sato M: Encephalomyelitis of cattle caused by Akabane virus in southern Japan in 2006. J Comp Pathol 2009, 140:187-193.

5. Kono R, Hirata M, Kaji M, Goto Y, Ikeda S, Yanase T, Kato T, Tanaka S, Tsutsui T, Imada T, Yamakawa M: Bovine epizootic encephalomyelitis caused by Akabane virus in southern Japan. BMC Vet Res 2008, 4:20.

6. Kurogi H, Inaba Y, Goto Y, Miura Y, Takahashi H: Serological evidence for the aetiologic role of Akabane virus in epizootic abortion arthrogryposis hydranencephaly syndrome in Japan, 1972-74. Arch Virol 1975, 47:71-83.

7. Stram Y, Brenner J, Braverman Y, Banet-Noach C, Kuznet-zova L, Ginni M: Akabane virus in Israel: a new virus lineage. Virus Res 2004, 104:93-97.

8. An DJ, Yoon SH, Jeong W, Kim HJ, Park BK: Genetic analysis of Akabane virus isolates from cattle in Korea. Vet Microbiol 2010, 140:49-55.

9. Ungar-Waron $\mathrm{H}$, Gluckman A, Trainin Z: ELISA test for the serodiagnosis of Akabane virus infection in cattle. Trop Anim Health Prod 1989, 21:205-210.

10. Ide S, Baba K, Tsuchimoto M, Nagano H, Kobayashi M, Goto Y: Detection of antibodies against Akabane virus in bovine sera by enzyme-linked immunosorbent assay. Vet Microbiol 1989, 20:275-280.

11. Crafford JE, Guthrie AJ, van Vuuren M, Mertens PP, Burroughs JN, Howell PG, Hamblin C: A group-specific, indirect sandwich ELISA for the detection of equine encephalosis virus antigen. J Virol Methods 2003, 112:129-135.

12. Tsuda T, Yoshida K, Yanase T, Ohashi S, Yamakawa M: Competitive enzyme-linked immunosorbent assay for the detection of the antibodies specific to akabane virus. J Vet Diagn Invest 2004, 16:571-576.

13. Narita M, Kawashima K: Detection of Akabane viral antigen and immunoglobulin-containing cells in ovine fetuses by use of immunoperoxidase staining. Am J Vet Res 1993, 54:420-424.

14. Haritani M, Hirogari Y, Kubo M, Sato H, Kobayashi M, Goto Y: Effects of antigen-retrieval pretreatments for immunohistochemical detection of Akabane viral antigen. J Vet Diagn Invest 2000, 12:361-363.

15. Yoshida K, Tsuda T: Rapid detection of antigenic diversity of Akabane virus isolates by dot immunobinding assay using neutralizing monoclonal antibodies. Clin Diagn Lab Immunol 1998, 5:192-198.

16. Akashi H, Onuma S, Nagano H, Ohta M, Fukutomi T: Detection and differentiation of Aino and Akabane Simbu serogroup bunyaviruses by nested polymerase chain reaction. Arch Virol 1999, 144:2101-2109.

17. Ohashi S, Yoshida K, Yanase T, Kato T, Tsuda T: Simultaneous detection of bovine arboviruses using single-tube multiplex reverse transcription-polymerase chain reaction. J Virol Methods 2004, 120:79-85.

18. Stram Y, Kuznetzova L, Guini M, Rogel A, Meirom R, Chai D, Yadin H, Brenner J: Detection and quantitation of akabane and aino viruses by multiplex real-time reverse-transcriptase PCR. J Virol Methods 2004 116:147-154.

19. Kinney RM, Calisher C: Antigenic relationships among simbu serogroup (Bunyaviridae) viruses. Am J Trop Med Hyg 1981, 30:1307-1318.

20. Notomi T, Okayama H, Masubuchi H, Yonekawa T, Watanabe K, Amino N, Hase T: Loop-mediated isothermal amplification of DNA. Nucleic Acids Res 2000, 28:E63.

21. Enosawa M, Kageyama S, Sawai K, Watanabe K, Notomi T, Onoe S, Mori $Y$, Yokomizo Y: Use of loop-mediated isothermal amplification of the IS900 sequence for rapid detection of cultured Mycobacterium avium subsp. paratuberculosis. J Clin Microbiol 2003, 41:4359-4365.

22. Poon LL, Leung CS, Chan KH, Lee JH, Yuen KY, Guan Y, Peiris JS: Detection of human influenza A viruses by loop-mediated isothermal amplification. J Clin Microbiol 2005, 43:427-430.

doi:10.1186/1743-422X-10-288

Cite this article as: Qiao et al:: Rapid detection of Akabane virus by a novel reverse transcription loop-mediated isothermal amplification assay (RT-LAMP). Virology Journal 2013 10:288. 